\title{
Pola Asuh Ayah dalam Perilaku Prososial Anak Usia Dini
}

\author{
Berta Laili Khasanah ${ }^{\circledR}{ }^{\bowtie}$, Pujiyanti Fauziah ${ }^{2}$ \\ Pendidikan Anak Usia Dini, Universitas Negeri Yogyakarta \\ DOI: $\underline{10.31004 / \text { obsesi.v5i1.627 }}$
}

\begin{abstract}
Abstrak
Keterlibatan pengasuhan ayah di Indonesia cukup tinggi. Penelitian ini bertujuan untuk mengetahui pola asuh ayah dalam perilaku prososial dan faktor yang mempengaruhi pola asuh ayah dalam perilaku prososial anak. Metode pengambilan data menggunakan angket dan observasi serta dianalisis secara statistik deskriptif dengan pendekatan kuantitatif. Hasil penelitian menunjukkan pola asuh ayah dalam perilaku prososial anak yaitu rata-rata ayah selalu menggunakan pola asuh autoritatif 36\%, kadang-kadang menerapkan pola asuh otoriter $39 \%$, dan kadang-kadang permisif sebesar $58 \%$, sedangkan dalam perilaku prososial kadang-kadang sebesar 35\%. Rendahnya pola asuh ayah dipengaruhi oleh faktor sosiodemografi yang meliputi usia, pendidikan, pekerjaan,dan pendapatan, sedangkan perilaku prososial dipengaruhi oleh moldeling, kebiasaan, dan komunikasi. Adapun dampak dari perilaku prososial yang menerapkan pola asuh permisif, anak menjadi agresif, emosional, dan rendah diri. Upaya dalam memfailitasi keterlibatan ayah seperti ikut parenting, studi edukasi, menjalin kerja sama dipuncak tema (pekerjaan) dan melibatkan komunikasi ayahanak agar perkembangan anak dapat berkembang secara optimal.
\end{abstract}

Kata Kunci: pola asuh ayah; prososial; anak usia dini.

\begin{abstract}
The involvement of foster care in Indonesia is quite high. This study aims to determine the pattern of foster care in prosocial behavior and the factors that influence parenting in the prosocial behavior of children. Methods of data collection using questionnaires and observations and analyzed statistically descriptive with quantitative approaches. The results showed father's parenting in the prosocial behavior of children ie the average father always uses authoritative parenting 36\%, sometimes applying 39\% authoritarian parenting, and sometimes permissive by $58 \%$, whereas in prosocial behavior sometimes equal to $35 \%$. The low parenting style is influenced by sociodemographic factors which include age, education, work, and income, while prosocial behavior is influenced by moldeling, habits, and communication. The impact of prosocial behavior applying permissive parenting children become aggressive, emotional, and inferior. Efforts to foster father involvement include parenting, educational studies, establishing cooperation at the top of the theme (work) and involving father-child communication so that child development can develop optimally.
\end{abstract}

Keywords: father's parenting; prosocial; early childhood.

Copyright (c) 2020 Berta Laili Khasanah, Pudji Yanti Fauziah

$\triangle$ Corresponding author:

Email Address : berthalaily@gmail.com (Jalan Samirono Baru No.46 Yogyakarta, Indonesia)

Received 29 June 2020, Accepted 7 August 2020, Published 11 September 2020 


\section{PENDAHULUAN}

Anak usia dini adalah anak yang berumur 0-8 tahun. NAEYC (National Association for The Education of Young Childre) membagi usia anak dari 0-3 tahun, 3-5 tahun, dan 6-8 tahun (Suryana, 2014: 1.6). Hal ini dikarenakan, anak memiliki pola pertumbuhan dan perkembangan fisik, kognitif, sosial emosional, kreativitas, nilai agama dan moral, bahasa dan komunikasi yang khusus sesuai dengan tahapan yang dilalui anak. Hal yang perlu diperhatikan yaitu, aspek sosial emosional dan moral anak. Pada aspek ini, keluarga menjadi salah satu benteng yang paling penting dalam menstimulasi.

Stimulasi lingkungan keluarga adalah subjek yang paling dekat dengan kehidupan anak. Sesuai dengan teori ekologi (Bronfenbrenner, 2004), perkembangan seseorang dimulai dari lingkungan mikro, yaitu keluarga. Sehingga penting untuk melatih aspek sosial dan moral anak. Karateristik aspek sosial, anak usia 3 sampai delapan tahun dapat di latih dengan belajar interaksi dengan orang lain, bekerja sama, berbaur, toleransi, menaati peraturan, mengenal sopan santun, bermain pura-pura, dan bermain dengan orang-orang dewasa (Permendikbud, 2014: 29). Stimulasi tersebut membutuhkan bimbingan dari orang dewasa untuk dijadikan role model bagi anak.

Role model setiap keluarga dalam menggunakan pola asuh yang dianut berbeda-beda. Sehingga pola asuh memberikan upaya orang tua yang konsisten dan persisten (Djamarah, 2014: 51). Anak beresiko memiliki permasalahan pada perilakukan ketika orang tua tidak konsisten dalam menerapkan kedisiplinan (Nauli et al., 2019). Namun, kekonsistenan juga dapat meningkatkan kepatuhan dari anak. Kekonsistenan ini akan menjadi bekal kebiasaan anak untuk diterapkan di dalam kehidupan bermasyarakat. Penerapan kekonsistenan tentu menerapkan dalam berbagai macam pola asuh.

Ada dua tipe pengasuhan ayah yang muncul secara konsisten yaitu acceptanceresponsiveness, yang mengacu pada perilaku positif yang terkait dengan penerimaan dan kehangatan, serta perilaku negatif seperti penolakan dan kritik; dan demandingness-control, yang mengacu pada perilaku negatif seperti kontrol orang tua dan overprotection, dan perilaku positif seperti promosi otonomi (Sigelman \& Rider, 2012:361). Hal ini diperkuat (Santrock, 2012:163) bahwa, pengasuhan orang tua dikategorikan menjadi pengasuhan otoriter, permisif, dan autoritatif.

Pertama otoriter parenting adalah gaya pengasuhan yang ketat yang menggabungkan demandingness-control yang tinggi dan rendah acceptance-responsiveness. Gaya pengasuhan otoriter bersifat membatasi dan mengontrol perilaku anak, bahkan orang tua tidak segansegan untuk menghukum anak jika tidak mengikuti arahannya. Dampak pengasuhan ini menimbulkan kecemasan, ketakutan, dan masalah komunikasi.

Kedua permissive parenting adalah pola asuh yang tinggi dalam acceptance-responsiveness namun rendah dalam demandingness-control. Pengasuhan permisif bersifat memanjakan cenderung memberikan kebebasan tanpa batas kepada anak sekalipun orang tua tampak bersikap hangat. Hal ini mengakibatkan anak kurang memiliki kontrol diri, sulit untuk patuh dan mengalami masalah dalam pergaulan. Sedangkan, pengasuhan permisif yang bersifat mengabaikan bercirikan orang tua tidak terlibat dalam kehidupan anak sehingga anak tidak merasakan kehangatan dan anak juga tidak mengenal batasan. Hal ini menimbulkan masalah masalah sosial dan emosional pada anak, antara lain anak kurang memiliki kontrol diri, kurang mandiri, dan memiliki harga diri yang rendah.

Ketiga authoritative parenting adalah pola asuh yang lebih fleksibel, dimana mereka menuntut dan melakukan kontrol, tetapi mereka juga menerima dan responsif. Beberapa pengasuhan ini akan berdampak pada perilaku anak. Pengasuhan autoritatif bersifat hangat dan mendukung kemandirian anak, meskipun demikian tetap ada kontrol atau batasan untuk perilaku anak (Sumargi \& Kristi, 2017: 187). Hal ini dilakukan supaya anak dapat hidup mandiri dan tumbuh sesuai dengan pilihan hidupnya dan jika anak berjalan ke arah yang salah orang tua dapat diingatkan dan diarahkan kembali. 
Oleh karena itu,diperlukan suatu upaya dalam meningkatkan keterlibatan pengasuhan ayah dengan cara seperti, aktif dalam mengikuti parenting, mengikuti outbound family, rekreasi, menjalin kerja sama dipuncak tema (pekerjaan), dan meningkatkan keterlibatan komunikasi ayah-anak agar tumbuh kembang anak dapat berkembang secara optimal. Tentunya dalam melaksankan, terdapat faktor yang mepengaruhi terkait dengan pola asuh yang dianut.

Faktor yang mempengaruhi pola asuh ayah yaitu situasi sosial-ekonomi orang tua (usia, latar belakang pendidikan, pekerjaan, penghasilan, tanggungan, bantuan sosial yang diperoleh); situasi tempat tinggal (status rumah, luas, ada tidaknya sekat, ventilasi, bahan dinding dan lantai, situasi area sekitar rumah, ketersediaan air bersih dan listrik); serta waktu keluarga (waktu orang tua berinteraksi dengan anak) (Indira, 2017: 2). Selain itu ada faktor sosiodemografi yang meliputi usia, jenis kelamin, pendidikan, pekerjaan, dan pendapatan (Desi, Tomasoa \& Soegijono, 2017:35).

Faktor yang mempengaruhi tersebut menjadi wujud tanggung jawab orang tua terhadap anak untuk membentuk perilaku anak. Hubungan pola asuh (angka dua orang tuaanak) dan hubungan coparenting (triad bersama-orang tua-anak) yang mandiri dan bersamasama berkontribusi pada perkembangan sosial anak (Cox \& Paley(1997) ; (Scrimgeour et al., 2013: 507). Perkembangan sosial ini penting untuk membentuk perilaku prososial anak agar anak tidak menjadi antisosial di masyarakat.

Perilaku prososial adalah tindakan atau kecenderungan untuk memberi manfaat kepada orang lain, seperti menunjukkan kepedulian terhadap orang lain dan kesediaan untuk membantu atau berbagi yang ditunjukkan dari perilaku pengasuhan, termasuk sensitivitas orang tua, pengaruh perilaku prososial anak-anak di awal perkembangan (Newton et al., 2014: 1). Perilaku prososial mencakup tindakan berbagi, menolong, kedermawanan, kerjasama, jujur, menyumbang (Matondang, 2016:37). Dalam penelitian ini, peneliti mengambil tindakan pada indikator berbagi, menolong, kerjasama, jujur, peduli, berderma, suka rela.

Sedangkan faktor yang mempengaruhi tindakan perilaku prososial yaitu bawaan dari lahir, kekonsistenan yang menjadi kebiasaan, role modeling orang tua, sifat yang sudah terinternalisasi oleh anak, usia yang bervariasi (Matondang, 2016: 37) serta waktu dan adanya dukungan dari luar. Sejalan dengan (Isnaningsih \& Rohman, 2019:174) intensitas peluang waktu stimulasi anak usia dini cendrung lebih banyak bergaul dengan orang tua atau keluarga di rumah dari pada di sekolah. Sehingga perkembangan anak secara langsung dipengaruhi oleh orang-orang sekitar seperti orangtua dan saudara kandung melalui interaksi keluarga.

Berdasarkan hasil penelitian dan observasi menjelaskan bahwa banyak penelitian berfokus hampir sepenuhnya pada ibu dan keterlibatan ayah yang diremehkan saat fokus di tahun-tahun awal kehidupan pendidikan (Sanders, M. R., \& Mazzucchelli, 2018: 3). Senada dengan Sanders dan Mazzucchelli, Coley \&Moris (2002); (Tekin, 2012: 5) menunjukkan bahwa, laporan ibu dalam keterlibatan ayah cenderung meremehkan peran ayah, dan, dalam banyak kasus, laporan ayah validitas laporan ibu tidak dapat dikonfirmasi. Dalam perilaku ibu juga berpengaruh lebih kuat daripada perilaku ayah dalam perilaku prososial anak, kepekaan ibu secara signifikan meramalkan empati anakdan perilaku prososial meningkat, tetapi sensitivitas ayah diprediksi tidak signifikan dalam empati anak dan perilaku prososial (Newton et al., 2014: 2).

Lingkup keterlibatan ayah di Indonesia dilihat secara Nasional dari studi-studi telah mengupas tentang peran ibu secara luas dan mendalam namun peran ayah seakan diabaikan. Hal ini disebabkan oleh keadaan di Indonesia yang menempatkan seorang laki-laki sebagai pengasuh ke dua dan pekerja di sektor publik dan wanita di sektor domestik sehingga menjadi salah satu faktor yang mempengaruhi penilaian masyarakat yaitu ayah berfungsi sebagai pencari nafkah dan pendidik yang tegas bagi anak-anaknya. Pada budaya timur seperti Indonesia, peran pengasuhan lebih banyak dipegang oleh istri atau ibu meskipun mendidik anak merupakan tanggung jawab bersama yang menunjukan presentase sebesar $65,31 \%$ dalam mengasuh (Sofiani et al., 2020). 
Selain itu, di Kabupaten semarang berdasarkan hasil penelitian,(Hidayati, F., Kaloeti, D. V.S., 2011: 1) keterlibatan pengasuhan ayah cukup tinggi yaitu $86 \%$, karena itu merupakan tanggung jawab bersama ayah dan ibu dalam menjalankan peran pengasuhan. Temuan mengenai rata-rata waktu yang digunakan ayah dalam berinteraksi dengan anak adalah 6 jam. Secara kuantitas dapat dikatakan bahwa, waktu ayah bersama anak cukup memadai untuk melakukan aktifitas bersama dengan anak.

Namun jika dilihat dari lingkup tempat tinggal peneliti pengasuhan ayah masih minim yaitu hanya $45 \%$, karena salah satu peran penting ayah di keluarga adalah economic provider, sehingga di hari libur kerja beberapa masih melakukan aktifitas untuk mencari nafkah dengan kerja sampingan.sehingga kasih sayang ayah tercurah Ketika hanya ada waktu luang untuk berusaha mengisi waktu dengan anak.

Praktik pengasuhan yang dilakukan ayah dan ibu didasarkan pada kebutuhan anak yang mencakup asah, asih, dan asuh. Sehingga Ayah dipandang dapat melakukan partisipasi dalam pengasuhan anak. Namun terkadang anak memandang ayah sebagai orang yang tinggi gengsinya atau prestisenya (Tekin, 2012: 5). Meskipun prestis ayah dianggap tinggi, keterlibatan ayah secara aktif dalam pengasuhan dan pendidikan anak memberikan efek positif pada berbagai aspek, termasuk meningkatkan perilaku positif dan adaptasi sosial anak, mengurangi masalah kedisiplinan anak, meningkatkan prestasi anak baik akademik maupun non akademik.

Bertolak belakang dari hasil penelitian (Simasari (2014); Bussa et al., 2018) diperoleh data bahwa 94,74\% responden ayah memiliki keterlibatan yang tinggi dengan anak. Hal ini disebabkan oleh perkembangan dan kemajuan bidang pendidikan seperti program parenting yang sudah dibuat oleh Direktorat Jenderal Pendidikan Anak Usia Dini, Nonformal, dan Informal (Ditjen PAUDNI) sejak tahun 2010. Sehingga dalam menerapkan perilaku prososial dapat dipertimbangkan.

Namun seiring perkembangan zaman yang semakin modern perilaku prososial pelanpelan mulai luntur dari masyarakat Indonesia. Hal ini ditandai dengan adanya sikap individual di lingkungan sekitar, dimana minimnya keterlibatan anak dengan teman seumuran atau sebaya yang menyebabkan hilangnya kesempatan untuk bersosialisasi.

Beberapa permasalahan prososial yang ditemukan peneliti berdasarkan observasi di TK Kuncup Melati III yang berjumlah 24 anak dari 13 anak laki-laki dan 11 anak perempuan menunjukan, yaitu ketidakmampuan menyesuaikan diri seperti anak suka jahil kepada teman, egosentris ketika bermain tidak ingin berbagi dengan teman, agresif dengan suka larilarian ketika sedang melakukan kegiatan dan berdoa serta menyebar mainan dan tidak dibereskan, perilaku antisosial yang rata-ratanya dibawah $45 \%$. Hal ini juga didukung dari penelitian (Hanifah and Ningrum, 2017:1) menemukan bahwa, 34,5\% anak mengalami masalah emosi berupa pemahaman emosi yang masih rendah. Perkembangan sosial emosi yang tidak tercapai secara optimal menunjukkan bahwa, anak belum dapat mengatur emosinya dengan baik dan kesulitan untuk berkomunikasi dengan orang lain karena kurangnya stimulasi komunikasi dengan orang tua.

Oleh karena adanya kontradiksi antara studi yang telah dilakukan sebelumnya sehingga penulis tertarik untuk mengkaji lebih dalam mengenai pola asuh ayah dalam perilaku prososial anak. Penelitian ini diharapkan mampu menggambarkan seberapa besar pola asuh ayah dalam perilaku prosisial anak usia 3-8 tahun serta faktor yang mempengaruhi pengasuhan ayah dalam berperilaku prososial anak usia 3-8 tahun akan pentingnya keterlibatan ayah dalam pengasuhan anak usia dini.

\section{METODOLOGI}

Penelitian dilakukan pada tanggal 16 Maret sampai 05 April 2020 di TK se-Kecamatan Kretek, Bantul, Yogyakarta. Populasi dalam penelitian ini adalah ayah yang memiliki anak usia 3-8 tahun. Sampel dalam penelitian ini adalah 68 responden dari TK se- Kecamatan Kretek. Pengambilan sampel dilakukan mengunakan teknik stratified random sampling. Dari 
17 TK se-Kecamatan Kretek diambil 2 TK yang digunakan secara keseluruhan yaitu di TK Kuncup Melati II ada 14 anak dan TK Kuncup Melati IV ada 18 anak, karena dengan alasan memiliki karateristik yang bervariasi untuk dijadikan kajian penelitian yang mewakili dari populasi, diambil sampel berdasar area yang mudah dijangkau dan lainnya menyebar secara acak karena untuk mewakili setiap populasi yang berjumlah 36 anak, masing-masing sampel 6 anak di TK Masyithoh Kalangan, TK Kuncup Melati I, TK Kuncup Melati V, TK Pembina, TK ABA Busuran, dan TK PKK 47 Genting.

Penelitian ini menggunakan variabel pengasuhan ayah dan perilaku prososial anak. Instrumen dalam penelitian ini menggunakan angket dan observasi. Validitas instrumen berdasarkan validitas konstruk (contruct validity) yang menggunakan pendapat ahli (experts judgment) (Sugiyono, 2013). Penyebaran angket sebagian dibantu dengan menggunakan google form yang ditujukan pada responden ayah yang memiliki anak usia dini dari usia 3-8 tahun. Sedangkan untuk memeroleh data perilaku prososial anak yaitu dengan observasi. Perilaku prososial yang diamati berupa kegiatan berbagi, bekerja sama, jujur, berderma, dan menolong. Alat pengumpulan data dalam penelitian ini menggunakan teknik angket (questionnaire), dan observasi.

Instrumen penelitian yang digunakan adalah angket yang berupa daftar pertanyaan tertutup. Kuesioner tersebut terdiri atas dua bagian yaitu: kuesioner pola asuh ayah yang meliputi pola asuh otoriter, autoritatif, dan permisif. Instrumen lembar observasi perilaku prososial yang meliputi berbagi, bekerja sama, jujur, berderma, dan menolong. Dalam indikator-indikator tersebut menggunakan skala Likert. Data dianalisis dengan menggunakan statistik deskriptif kuantitatif. Kesimpulan diambil berdasarkan kriteria dasar.

Untuk lebih lengkapnya dapat dilihat pada gambar di bawah ini:

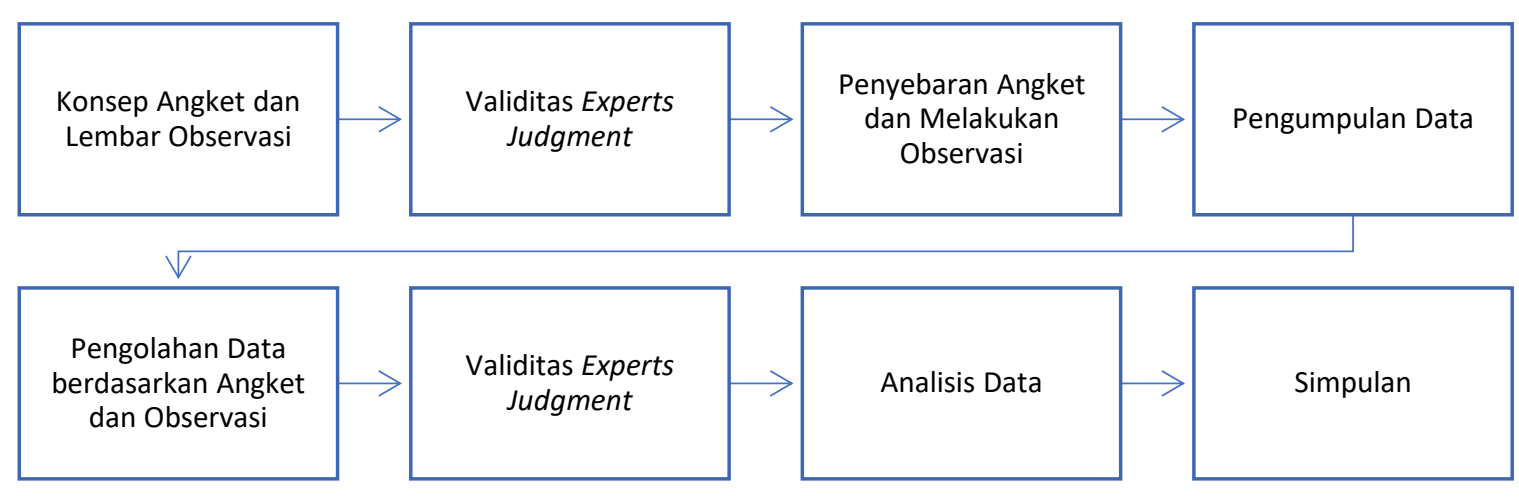

Gambar 1. Desain Penelitian

\section{HASIL DAN PEMBAHASAN}

Berdasarkan hasil validasi instrumen berdasarkan expert Judgment diperoleh berdasarkan perhitungan menunjukkan koefisien reliabilitas skala pola asuh otoriter sebesar 0,715 , koefisien reliabilitas skala pola asuh autoritatif sebesar 0,740, koefisien reliabilitas skala pola asuh permisif sebesar 0,742 , dan koefisien reliabilitas skala perilaku prososial sebesar 0,873 . Sehingga hasil seluruh koefisien reliabiltas tersebut dikatakan reliabel dan cukup memuaskan bagi tujuan pengukuran dalam penelitian ini.

Sehingga berdasarkan kuisioner mengenai variabel-variabel penelitian yang akan diteliti menurut indikator-indikator pola asuh ayah yang meliputi pola asuh autoritatif, otoriter, dan permisif dan indikator perilaku prososial anak yang meliputi berbagi, bekerja sama, jujur, berderma, dan menolong. Rata-rata hasil pola asuh ayah dalam perilaku prososial anak dapat dilihat dalam Tabel 1 dibawah ini. 
Tabel 1. Rata-Rata Pola Asuh Ayah dalam Perilaku Prososial Anak

\begin{tabular}{lccccc}
\hline \multicolumn{1}{c}{ Indikator } & Selalu & Sering & Kadang-kadang & Tidak pernah & SD \\
\hline Otoriter & $14 \%$ & $13 \%$ & $39 \%$ & $35 \%$ & 1.5 \\
Autoritatif & $36 \%$ & $27 \%$ & $32 \%$ & $6 \%$ & 2.3 \\
Permisif & $13 \%$ & $13 \%$ & $58 \%$ & $17 \%$ & $3 \%$ \\
Prososial & $22 \%$ & $32 \%$ & $35 \%$ & $11 \%$ & 2.5 \\
\hline
\end{tabular}

Peneliti menggunakan kriteria dasar menurut Arikunto (Arikunto, 2005: 44) yaitu:

Tabel 2. Kriteria Dasar menurut Arikunto

\begin{tabular}{cll}
\hline No & \multicolumn{1}{c}{ Kriteria } & Nilai \\
\hline 1 & Sangat Baik & $81-100$ \\
2 & Baik & $61-80$ \\
3 & Cukup & $41-60$ \\
4 & Kurang & $21-40$ \\
5 & Sangat Kurang & $0-20$ \\
\hline
\end{tabular}

Pola Asuh Ayah Otoriter

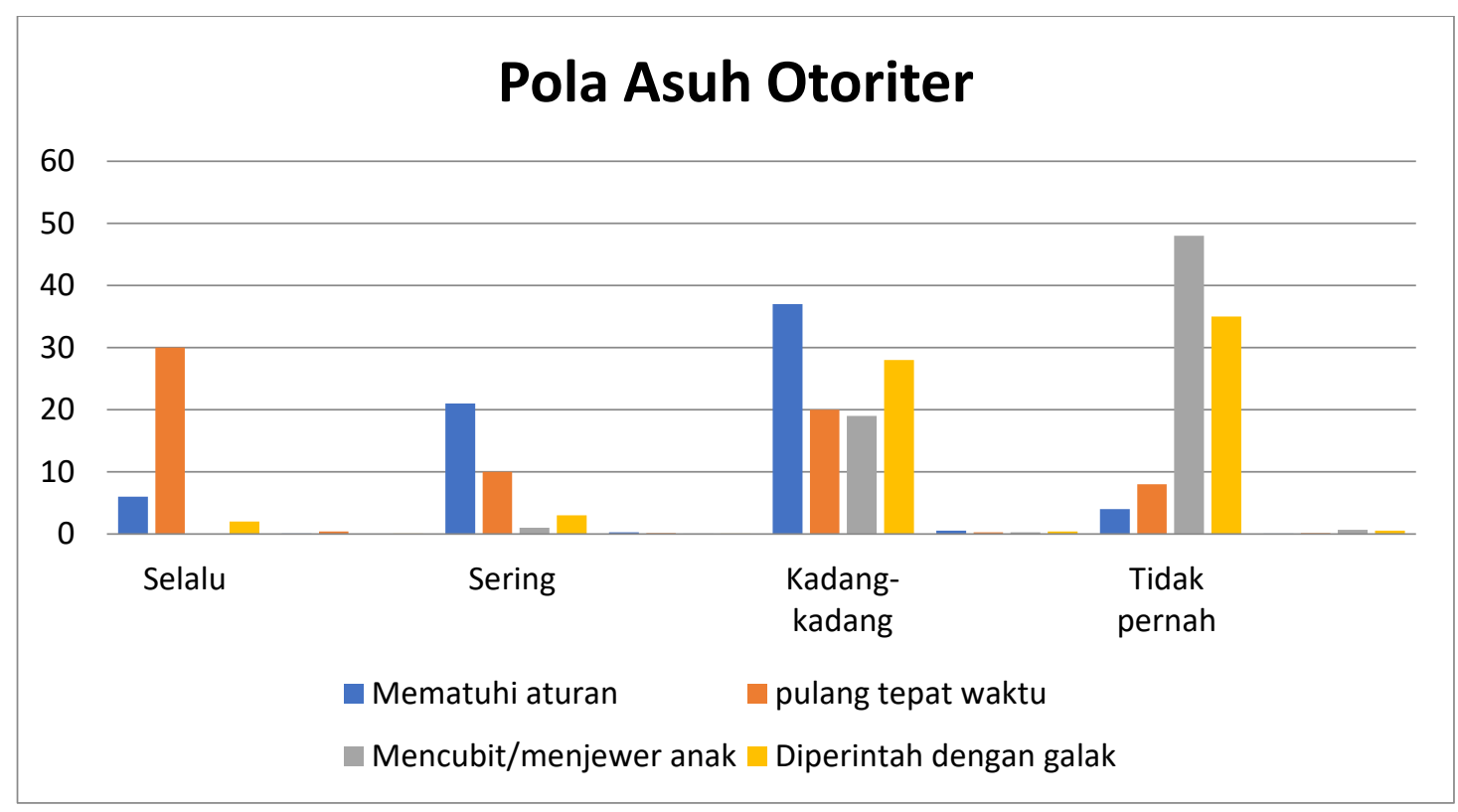

Gambar 2. Grafik hasil presentase pola asuh ayah otoriter

Gambar 2 menunjukkan bahwa, persentase mengenai pola asuh ayah otoriter yang tinggi dan selalu dilakukan ayah adalah anak harus pulang tepat waktu sebanyak $44,1 \%$ (30 anak) yang masuk kedalam kategori cukup. Dalam kategori kadang-kadang yang paling tinggi adalah anak harus mematuhi aturan yaitu sebesar 57\% (39 anak) yang masuk kriteria cukup. Perilaku pola asuh yang hampir tidak pernah dilakukan ayah yaitu mencubit/ menjewer yang menunjukkan hasil penelitian sebesar $71 \%$ (48 anak) yang masuk ke dalam kategori baik.

Berdasarkan hasil penelitian tersebut artinya pola asuh ayah tidak selamanya bersifat otoriter. Dikarenakan sifat dari pola asuh otoriter tegas, sehingga ayah selalu memberikan peraturan yang harus di taati oleh anak dan harus pulang tepat waktu. Hal ini sejalan dengan 
(Purnamasari, 2015:83)(Purnamasari, 2015) bahwa, pola asuh otoriter memiliki peran ayah sebagai protector, monitor dan disiplin, ayah yang menerapkan yang memiliki peraturan yang harus ditaati, karena ini sebagai protector untuk memberikan perlindungan dan mengontrol anak agar terhindar dari kesulitan atau bahaya yang mengancam keamanan diri mereka ketika orang tua tidak bersamanya. Hal ini juga sejalan dengan (Murti, 2013: 157) ada tiga cara mengajarkan nilai yaitu memberika aturan, memberikan pertimbangan, dan memberikan contoh.peneliti menemukan bahwa, meskipun ayah menerapkan pola asuh otoriter namun ayah paham untuk tidak pernah memperlakukan seperti membentak dengan nada tinggi/ galak dan melakukan kekerasan fisik seperti mencubit atau menjewer. Hal ini dikarenakan jika ayah menggunakan kekerasan baik secara fisik ataupun psikologis dengan benar dan dengan ketidakmengertian cara efektis yang terjadi justru yang diharapkan tidak dapat dicapai. Hal ini didukung oleh (Hidayati, F., Kaloeti, D. V. S., 2011:8) sebagai ayah perlu memahami benar dalam makna mendidik dan menghilangkan bahwa mendidik adalah menghukumm dan melarang ataupun memerintah dengan kekerasan. Dengan adanya pemahaman ini dipercaya dapat meningkatkan keterampilan ayah akan menghindarkan dari bentuk kekerasan fisik ataupun psikologis.

\section{Pola Asuh Autoritatif}

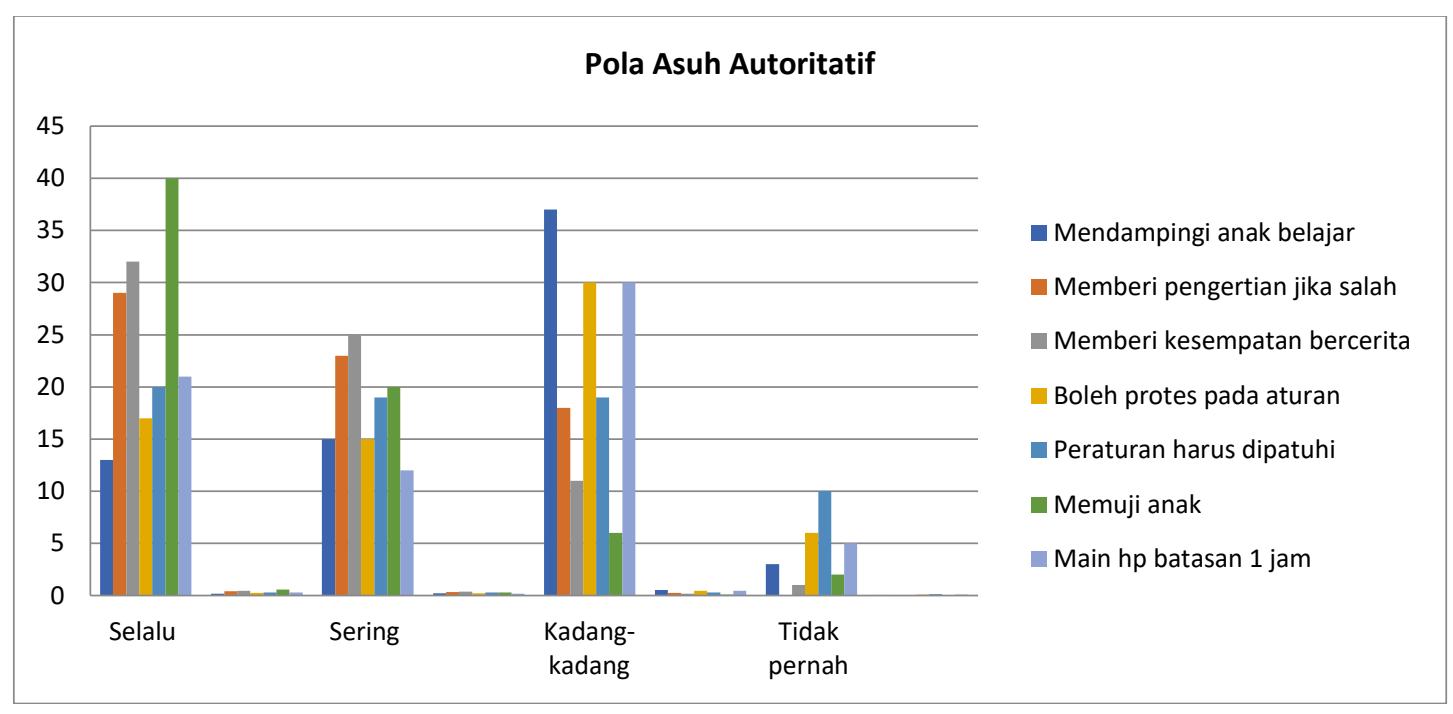

Gambar 3. Grafik Hasil Presentase Pola Asuh Ayah Autoritatif

Gambar 3 menunjukkan bahwa, pola asuh ayah autoritatif yang selalu diterapkan yaitu memuji anak yang menunjukkan hasil 59\% (40 anak) yang masuk kedalam kategori cukup, ayah sering memberi kesempatan anak untuk bercerita sebanyak 37\% (25 anak) dalam kategori kurang, ayah selalu memberi pengertian anak jika salah sebanyak $43 \%$ ( 29 anak) yang masuk kategori cukup, anak selalu mematuhi peraturan sebanyak 29\% (20 anak) yang masuk dalam kategori kurang. Pola asuh ayah yang kadang-kadang diterapkan diperoleh presentase tertinggi yaitu mendampingi anak ketika belajar sebesar 54\% (37 anak) yang masuk dalam kategori cukup karena kebanyakan ibu yang mendampingi anak dalambelajar, anak kadangkadang protes apabila peraturan tidak sesuai dengan anak yang menunjukkan sebesar $44 \%$ (30 anak) yang masuk dalam kategori cukup. Dalam pola asuh ayah dengan tipe otoritatif dapat dibilang cenderung positif.

Berdasarkan hasil penelitian pada pola asuh ayah yang menerapkan autoritatif cukup banyak. Hal ini karena karateristik dalam pola asuh autoritatif lebih memperlakukan anak sesuai dengan keinginan dan tingkat perkembangan anak. Namun juga setiap pola pengasuhan harus diperkuat dengan batasan norma-norma yang menghindarkan perilaku menyimpang agar memberikan rasa nyaman. Pola asuh yang di gunakan peneliti seperti pada 
kegiatan memperbolehkan bermain hp dengan batasan hanya 1 jam, memberi pengertian ketika salah. Hal ini senada dengan (Sofiani et al., 2020:775) adanya batasan tersebut sejatinya bukan bermaksud membuat anak terkekang namun justru membuat anak merasa terlindungi. Lain halnya pola asuh ayah yang ada di barat yang memberikan kebebasan pada anaknya, karena dipercaya untuk belajar hidup mandiri sejak dini dan kelak dapat tumbuh dengan pilihannya sendiri.

Ayah jarang dalam mendampingi anak belajar karena kebanyakan ibu yang mendampingi anak dalam belajar. Hal ini karena para ibu menyatakan dekat secara emosional dengan anak-anaknya karena merawat sendiri sejak bayi sedangkan ayah hanya mengasuh ketika ibu sedang repot mengurus dapur dan keadaan tertentu saja. Sehingga intensitas melakukan interaksi dengan ayah hanya sedikit.

\section{Pola Asuh Ayah Permisif}

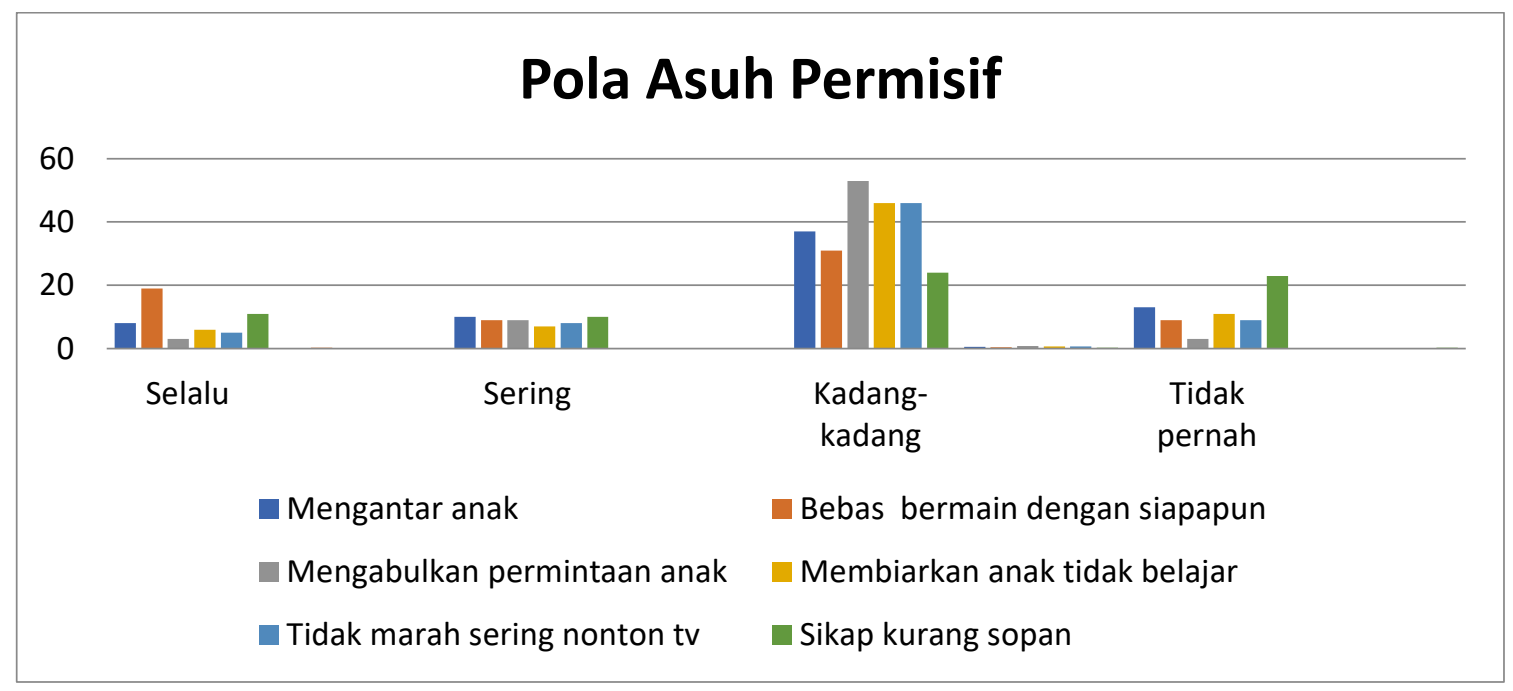

Gambar 4. Grafik HasilPresentase PolaAsuhAyahPermisif

Gambar 4 menunjukkan bahwa, dalam pola asuh ayah tipe permisif atau cenderung mengabaikan di dalam kategori selalu, sering dan tidak pernah cenderung sangat rendah dan yang paling tinggi yaitu intensitas kadang-kadang. Pola asuh ayah tipe permisif yang cenderung tinggi pada intensitas kadang-kadang yaitu mengabulkan permintaan ayah $78 \%$ (53 anak) yang masuk dalam kategori baik, membiarkan anak menonton tv dan membiarkan anak tidak belajar menunjukkan hasil sebesar 68\% (46 anak) yang masuk dalam kategori baik, mengantar anak menunjukkan sebesar 54\% (37 anak) yang masuk dalam kategori cukup, bebas bermain dengan siapapun menunjukkan presentase sebesar $46 \%$ (31 anak) dalam kategori cukup, dan sikap kurang sopan yang menunjukkan intensitas kadang-kadang sebesar 35\% (24 anak) yang masuk kategori kurang. Hal yang tidak pernah dilakukan ayah dalam mengasuh anak yang paling tinggi yaitu megajarkan sikap kurang sopan yang menunjukkan 34\% (23 anak) dalam kategori kurang.

Berdasarkan data yang diperoleh kadang-kadang diterapkan oleh ayah cukup tinggi. Adanya beban pekerjaan ayah yang tinggi menyebabkan waktu dan tenaga ayah banyak tersita untuk pekerjaan. Sehingga ayah menjadi kurang memperhatikan pengasuhan anaknya dan memberikan kebebasan terhadap anak tanpa bisa mengontrolnya. Hal ini senada dengan (Pasaribu et al., 2013:166) gaya pengasuhan permisif dengan kehangatan tinggi namun tuntutan/kontrol perilaku rendah lebih banyak diterapkan oleh ayah dibandingkan dengan ibu. Hal ini, menimbulkan perilaku pada anak seperti suka memberontak, agresif, impulsif dan kurang meiliki rasa percaya diri, dan prestasi yang rendah. 


\section{Perilaku Prososial}

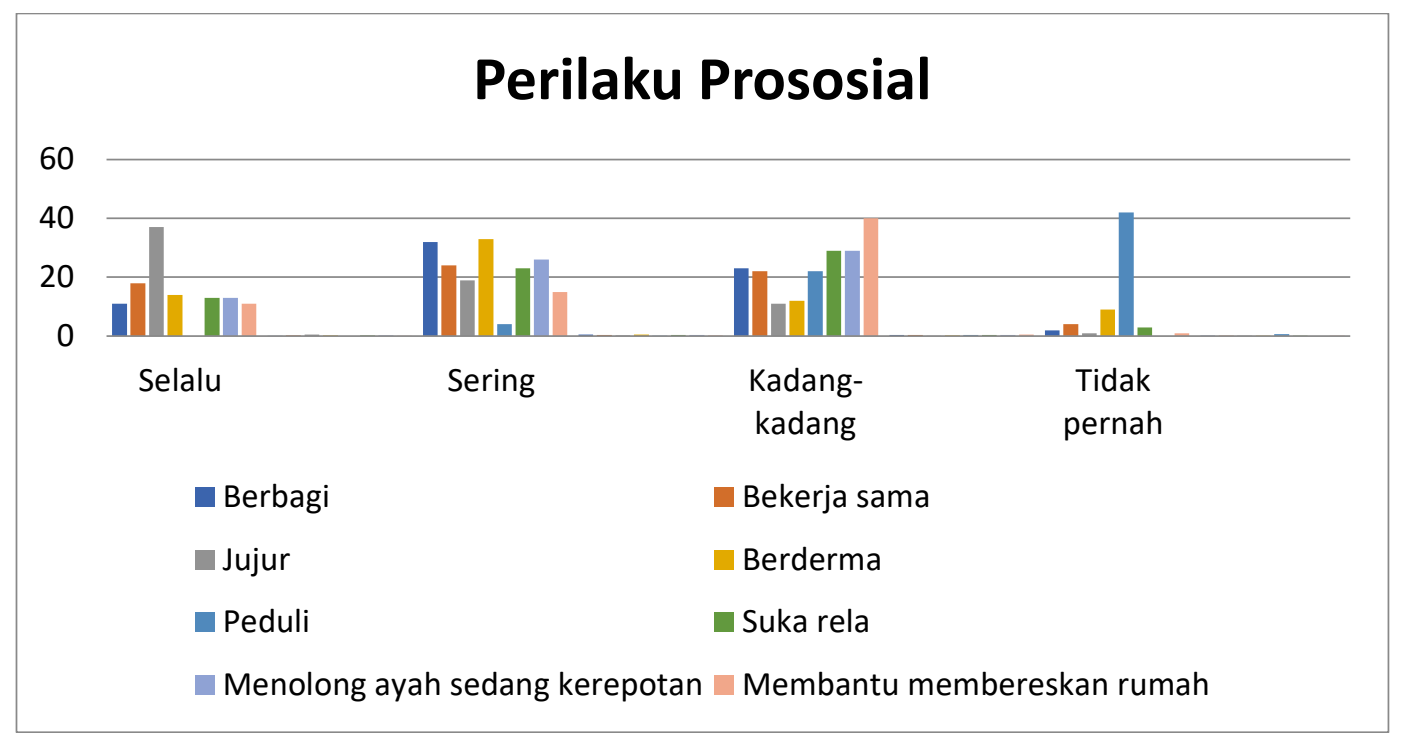

Gambar 5. Grafik Hasil Presentase Perilaku Prososial

Gambar 4 menunjukkan bahwa, dalam perilaku prososial anak usia dini yang selalu diterapkan yaitu sikap jujur yang menunjukkan hasil 54\% (37 anak) yang masuk kedalam kategori cukup, intensitas sering dari berderma menunjukkan hasil sebesar 49\% (33 anak) yang masuk kategori cukup, perilaku berbagi dengan intensitas sering menunjukkan sebesar 47\% (32 anak) yang masuk kategori cukup, perilaku bekerja sama dengan intensitas sering menunjukkan sebesar 35\% (24 anak) masuk kategori kurang. Intensitas kadang-kadang yang sering muncul yaitu membantu membereskan mainan sebesar 59\% (40 anak) yang masuk dalam kategori cukup, perilaku suka menolong dan suka rela menunjukkan hasil yang sama yaitu 43\% (29 anak) yang masuk dalam kategori cukup. Sikap peduli dengan intensitas tidak pernah menunjukkan pesentase yang tertinggi yaitu 62\% (42 anak) yang masuk dalam kategori baik. Sehingga dalam stimulasi tentang kepedulian sesama teman masih kurang.

Berdasarkan hasil penelitian dari perilaku prososial yang selalu dilakukan ayah adalah jujur, karena ayah cenderung tidak pernah berbohong dalam mengatakan suatu hal. Selain itu peneliti menemukan bahwa keterlibatan ayah dalam mengembangkan sikap empati masih kurang seperti peduli, berbagi, suka rela. Hal ini karena adanya faktor seperti pembiasaan yang tidak konsisten, peran modeling yang kurang, kurangnya dukungan dari luar.

Perilaku ibu juga berpengaruh lebih kuat daripada perilaku ayah dalam perilaku prososial anak, kepekaan ibu secara signifikan meramalkan empati anak dan perilaku prososial meningkat, tetapi sensitivitas ayah diprediksi tidak signifikan dalam empati anak dan perilaku prososial (Newton et al., 2014: 2). Ayah juga memiliki bersikap dan bertindak secara lebih serius dalam memperkenalkan apa yang tepat sebagai sifat maskulin dan feminim jika dibanding dengan ibu. Dengan begitu, dapat menimbulkan rasa nyaman terhadap anak. Pola asuh ayah yang kondusif seperti merasa disayangi, dilindungi, dianggap berharga, dan diberi dukungan akan memberi semangat positif dalam pembentukan perilaku prososial anak. Sejalan dengan (Isnaningsih \& Rohman, 2019:174) bahwa intensitas peluang waktu stimulasi perilaku prososial anak usia dini cendrung lebih banyak bergaul dengan orang tua atau keluarga di rumah dari pada di sekolah. Sehingga perkembangan anak secara langsung dipengaruhi oleh orang-orang sekitar seperti orangtua dan saudara kandung melalui interaksi keluarga.

Berdasarkan dari hasil penelitian secara keseluruhan yang diperoleh ternyata tidak ada pola asuh yang paling baik diantara tiga pola asuh yang disebutkan karena ketiga pola asuh berada dalam kategori cukup. Namun, jika ingin hasilnya baik,orang tua harus mampu 
mengkombinasikan dengan pola asuh yang lainnya dan membangun keterlibatan yang lebih dekat dengan anak. Perilaku prososial yang rendah, karena adanya penerapan pola asuh yang kurang konsisten dan kurang stimulsi. Hal ini senada dengan (Wiyani, 2016: 197) bahwa, tidak ada pola asuh yang paling baik diantara tiga pola asuh yang disebutkan. Sebaiknya orangtua tidak hanya satu menerapkan pola asuh ketika mendidik anak. Namun orang tua harus mampu mengkombinasikan ketiga bentuk pola asuh tersebut. Anak yang dibesarkan dengan pola asuh kombinasi mempunyai kesempatan 1,9 kali lebih tinggi terlambat perkembangannya dibandingkan anak yang dibesarkan dengan pola asuh demokratis (Handayani et al., 2017:52).

\section{Faktor Yang Mempengaruhi Pola Asuh Ayah}

Dalam penerapan pola asuh otoriter ternyata ayah tidak pernah melakukan kekerasan fisik seperti menjewer, mencubit, dan memerintah dengan galak namun menggunakan cara orang tua sendiri. Faktor yang mempengaruhi yaitu budaya yang diterapkan orang tua yang sudah mulai sadar terhadap pola asuh yang tidak melulu mempertahankan konsep tradisional. Kini pola asuh ayah mulai terbuka, sebab ayah sudah mengetahui dampak jika anak diperintah dan diberi hukuman dalam bentuk fisik yang terjadi psikis anak menjadi teguncang, anak juga menjadi penakut. Hal ini sejalan dengan (Novianty \& Gunadarma, 2016: 18), sikap otoriter orang tua akan berpengaruh pada profil perilaku anak. Psikologis anak yang mendapat pengasuhan otoriter akan menjadi mudah tersinggung, penakut, pemurung, tidak bahagia, mudah terpengaruh, mudah stress, tidak mempunyai arah masa depan yang jelas dan tidak bersahabat.

Hal sebaliknya oleh (Avid W. Shwalb dan Barbara J. Shwalb, 2013:1) yang memiliki pernyataan bahwa ayah ketat, ibu yang penuh kasih, ayah yang keras, ibu yang penuh kasih sayang. Artinya ayah memiliki sifat yang kaku, keras serta memiliki kekuasaan yang lebih mengontrol dalam pengasuhan dan ibu sebagai pemberi kasih sayang untuk melindungi anak

Pola asuh ayah dengan tipe autoritatif yang selalu diterapkan menunjukkan hasil penelitian rata-rata 36\% yang masuk ke dalam kategori kurang. Meskipun rata-rata menunjukkan $36 \%$ ada beberapa indikator yang menunjukkan hasil yang tinggi. Berdasarkan hasil penelitian pola asuh ayah dengan tipe autoritatif cenderung selalu memuji anak sebesar 58\% (40 anak) dalam melakukan sesuatu, ayah selalu memberi kesempatan anak untuk bercerita, ayah kadang-kadang juga mendampingi anak ketika belajar. Hal ini sesuai dengan penelitian yang dilakukan (Lidyasari, 2013:1) bahwa, dalam pola asuh otoritatif menjadi jalan terbaik dalam pembentukan karakter anak. Karena pola asuh otoritatifini bercirikan orang tua bersikap demokratis, menghargai dan memahami keadaan anak dengan kelebihan kekurangannya sehingga anak dapat menjadi pribadi yang matang, supel, dan bisa menyesuaikan diri dengan baik.

Adanya rata-rata yang rendah ini dipicu oleh faktor sosiodemografi yang meliputi usia, jenis kelamin, pendidikan, pekerjaan, dan pendapatan yang masih rendah. Sebanyak 68 responden yang diambil peneliti, usia ayah masih usia produktif mulai dari usia 15-64 tahun.

Kebanyakan pendidikan terakhir ayah 10\% lulusan SD, 45\% lulusan SMP dan SMA. Ayah yang lebih berpendidikan dan ayah yang lebih muda akan memiliki keterlibatan yang lebih tinggi dalam tingkat keterlibatan pegasuhan dan perawatan anak (Seward \& Rush, 2015:7).

Dilihat dari pekerjaan ayah kebanyakan $43 \%$ sebagai buruh, 35\% sebagai wiraswasta, 9\% sebagai guru, 13\% sebagai karyawan swasta.. Adanya faktor yang berhubungan dengan pekerjaan ayah secara signifikan terkait dengan keterlibatan ayah dalam merawat anak karena dimensi sikap seperti kebapakan dan gender (Yeung, 2013: 141). Pekerjaan yang lebih besar dan waktu perjalanan pulang pergi merupakan kendala terbesar dalam keterlibatan ayah untuk mengasuh anak. Sehingga, keterlibatan dalam mengasuh anak kebanyakan diasuh oleh ibu. Ayah hanya melibatkan dalam mengasuh anak ketika hanya memiliki waktu luang 
saja sebesar $45 \%$ dan sisanya digunakan ayah untuk mencari tambahan penghasilan. Meskipun ayah mencari penghasilan tamahan pendapatan ayah dari 68 responden perbulan yaitu termasuk kedalam golongan menengah kebawah yaitu Rp.900.000 - 200.000.

Hal ini diperkuat oleh (Yeung, 2013: 144) bahwa, tingkat keterlibatan ayah Asia cenderung lebih rendah daripada pria di Barat, masyarakat terlepas dari partisipasi perempuan Asia yang sama tinggi di pasar tenaga kerja, ayah-ayah ini mungkin memainkan peran yang lebih besar dalam pendidikan anak-anak mereka dalam hal-hal terkait prestasi daripada yang telah mereka dilaporkan sebelumnya. Di Indonesia beberapa konteks unik yang membentuk kebapaan Asia disorot dalam tubuh kerja yaitu norma dan nilai-nilai gender tradisional yang kuat tetap kuat.

Hasil penelitian menunjukkan bahwa tingginya pola asuh ayah tipe permisif dengan intensitas kadang-kadang diterapkan menunjukkan sebesar 58\% dengan kategori cukup. Orang tua dengan gaya pengasuhan permisif memiliki kasih sayang tinggi, tetapi kontrol rendah, orang tua memberikan kebebasan tanpa batasan dan aturan kepada anak, orang tua tidak memberikan hukuman atas kesalahan yang anak lakukan. Dalam penelitian ini pola asuh permisif yang diterapkan yaitu mengabulkan permintaan anak, mengantar anak ke sekolah, membiarkan anak menonton tv dan tidak belajar, bebas bermain dengan siapapun, membiarkan anak berperilaku kurang sopan.

Tingginya pola asuh ayah tipe permisif ini, karena dipengaruhi oleh faktor keadaan sosial ekonomi, terlihat dari kebanyakan penghasilan orang tua menengah ke bawah dengan status pekerjaan sebagai buruh sebesar $43 \%$. Adanya kesibukan orang tua dalam mencari nafkah menjadikan pengawasan yang sangat longgar serta memberikan kesempatan pada anaknya untuk melakukan sesuatu tanpa pengawasan ayah atau orang tua yang cukup. Hal ini senada dengan (Hurlock (2002); Muslima, 2015: 93), orang tua dari kelas menengah rendah cenderung lebih keras/lebih permisif dalam mengasuh anak). Menurut(Lestari, 2012: 48), dimana orang tua membiarkan anak untuk mengatur dirinya sendiri dan tidak terlalu mendorongnya untuk memenuhi standar ekternal. Sehingga anak dibiarkan untuk berfikir dalam mencapai keberhasilan.

Keterlibatan komunikasi juga menjadi faktor yang mempengaruhi dalam pola asuh ayah. Anak yang seharusnya distimulasi atau diberi perhatian menjadi kurang diperhatikan.Sejalan dengan hasil penelitian (Newton et al., 2014:1) bahwa intensitas bertemu/waktu berpengaruh dan tergantung pada kualitas masing-masing hubungan orang tua - anak danjumlah waktu yang dihabiskan bersama.Hal lain juga didukung oleh (IshiiKuntz, 2013: 250) bahwa, faktor terkait pekerjaan secara signifikan mempengaruhi keterlibatan ayah dalam perawatan anak.

Berdasarkan hasil penelitian, perilaku prososial menunjukkan rata-rata menerapkan dengan intensitas kadang-kadang sebesar 35\%. Bentuk-bentuk perilaku prososial yang diteliti dalam penelitian ini yaitu berbagi, peduli, menolong, bekerja sama, bertindak jujur, dan berderma. Perilaku prososial yang selalu dan sering dilakukan anak usia dini yaitu jujur, berderma, berbagi dan bekerja sama. Hal ini karena, adanya faktor yang mempengaruhi yaitu lingkungan keluarga dan sekolah saling mempengaruhi. Anak adalah peniru yang ulung. Dimana ketika anak melihat perilaku yang dirasanya sesuai maka anak akan menirunya. Dalam perilaku prososial ini dibutuhkan suatu kekonsistenan dan persisten dalam menstimulasi. Faktor bawaan yang telah terinternalisasi akan diterapkan di manapun oleh anak.

Para ayah sudah meningkatkan partisipasi mereka dalam pengasuhan anak (Ranson, 2015: 1). Gambaran ayah yang terlibat yang baru sudah berbeda dibandingkan gambaran ayah yang terlibat pada masa lampau. Hal ini terbukti dari hasil penelitian penelitian lain pengasuhan otoritatif berhubungan secara positif dengan perilaku prososial seperti tingkat kejujuran dan tanggung jawab pada anak (Pasaribu et al., 2013: 2). Rendahnya sikap peduli terhadap teman yang menangis sangat tinggi, karena adanya perbedaan pola asuh ayah dan ibu. Anak yang diasuh ayah cenderung kurang dalam menanamkan sikap empati terhadap 
orang lain karena kurangnya komunikasi dan waktu bersama, sedangkan pola yang diasuh ibu cenderung memiliki sikap empati yang lebih tinggi karena adanya intensitas waktu yang lebih, pembiasaan yang konsisten dan modeling. Sehingga faktor yang mempengaruhi sikap prososial karena adanya waktu yang lebih, pembiasaan secara konsisten dan modeling.

Beberapa penelitian telah memperkuat bahwa, perilaku ibu memiliki pengaruh yang lebih kuat daripada perilaku ayah pada perilaku prososial anak-anak. Gaya ibu, perilaku, dan kognisi diprediksi berkaitan dengan perilaku prososial dalam jenis kelamin anak-anak, sementara gaya ayah, perilaku,dan kognisi tidak terkait dengan prososial anak-anak dalam perilaku dengan beberapa pengecualian (Newton et al., 2014: 2) Kepekaan ibu secara signifikan meramalkan empati anakdan perilaku prososial, tetapi sensitivitas ayah tidak signifikan prediksi empati anak dan perilaku prososial.

Pendapat ini diperkuat oleh (Ferreira et al., 2016: 12) bahwa, perbedaan pola asuh ibu dan ayah bisa menjadi sama sensitif dan responsifnya, ibu cenderung verbal dan didaktik dalam permainan mereka, sementara ayah cenderung terlibat dalam permainan yang lebih menstimulasi dan merangsang secara fisik.Selain itu faktor keterlibatan ayah yang kurang menjadikan intensitas bertemu/waktu dan menghabiskan waktu bersama menjadi terbatas. Komunikasi yang baik yang dilakukan oleh kedua orang tua memiliki dampak besar dalam perilaku prososial yang diterapkan.

Perilaku prososial dari 28 anak laki-laki dan 40 anak perempuan di masa kanak-kanak berdasarkan hasil penelitian menunjukkan perilaku menantang dan memaksa menimbulkan lebih keras mengasuh anak ketika orang tua memiliki keterampilan yang buruk dan dukungan sosial yang rendah, dan hubungan antara praktik pengasuhan anak dan paksaan anak-anak untuk menghasilkan umpan balik positif, semakin meningkatkan anak-anak menjadi perilaku antisosial. Faktor yang mempengaruhi ini akan berdampak pada dukungan pembentukan kepribadian yang prososial, percaya diri, dan mandiri dan diharapkan menumbuhkan sikap prososial anak. hal ini diperlukan suatu upaya yntyk meningkatkan keterlibatan ayah dalam perilakuprososial anak dengan cara mengikuti parenting, studi edukasi, menjalin kerja sama dipuncak tema (pekerjaan) dan melibatkan komunikasi ayahanak agar perkembangan anak dapat berkembang secara optimal.

\section{SIMPULAN}

Berdasarkan hasil penelitian dapat ditarik kesimpulan bahwa, pola asuh ayah dalam perilaku prososial anak yaitu rata-rata ayah selalu menerapkan pola asuh autoritatif sebesar $36 \%$ dengan kategori kurang, intensitas kadang-kadang dari pola asuh permisif sebesar 58\% dengan kategori cukup, intensitas kadang-kadang dari pola asuh otoriter sebesar 39\% dengan kategori kurang, serta intensitas kadang-kadang dari perilaku prososial sebesar 35\% dengan kategori kurang. Rendahnya hasil pola asuh ayah dipengaruhi oleh faktor sosiodemografi yang meliputi usia, pendidikan, pekerjaan, dan pendapatan serta keterlibatan intensitas komunikasi sedangkan rendahnya prilaku prososial karena dipengaruhi oleh modeling dari orang tua, komunikasi, dan kebiasaan.

\section{UCAPAN TERIMA KASIH}

Terimakasih kepada Allah, orang tua dan kepala sekolah TK se-Kecamatan Kretek yang telah mendukung dan memberi izin penelitian serta kepada para orang tua khususnya ayah yang bersedia menjadi subjek penelitian.

\section{DAFTAR PUSTAKA}

Arikunto. (2005). Manajemen Penelitian. PT. Rineka Cipta.

Avid W. Shwalb, Barbara J. Shwalb, M. E. L. (2013). Fathers in Cultural Context. CRC Press.

Bronfenbrenner, U. (2004). Ecological Systems Theory. In Encyclopedia of Psychology, Vol. 3. https:// doi.org/10.1037/10518-046 
DOI: 10.31004/obsesi.v5i1.627

Bussa, B. D., Kiling-Bunga, B. N., Thoomaszen, T. W., \& Kiling, I. T. (2018). Persepsi Ayah Tentang Pengasuhan Anak Usia Dini. Jurnal Sains Psikologi, 7(2), 126-135.

Desi, Tomasoa, S. J., \& Soegijono, S. P. (2017). Well-being: Studi Sosiodemografi di Ambon. Jurnal Keperawatan Muhhamadiyah, 2(2).

Djamarah, S. B. (2014). Pola asuh orang tua dan komunikasi dalam keluarga.PT.Rineka Cipta.

Ferreira, T., Cadima, J., Matias, M., Vieira, J. M., Leal, T., \& Matos, P. M. (2016). Preschool Children's Prosocial Behavior: The Role of Mother-Child, Father-Child and TeacherChild Relationships. Journal of Child and Family Studies, 25(6), 1829-1839. https://doi.org/10.1007/s10826-016-0369-x

Handayani, D. S., Sulastri, A., Mariha, T., \& Nurhaeni, N. (2017). Penyimpangan Tumbuh Kembang Anak dengan Orang Tua Bekerja. Jurnal Keperawatan Indonesia, 20(1), 48-55. https://doi.org/10.7454/jki.v20i1.439

Hanifah and Ningrum. (2017). Gambaran Hasil Deteksi Dini Masalah Mental Emosional Pada Anak Prasekolah Usia 36 Sampai 72 Bulan Di Playgroup Dan Tk Cherry Kids Club Islamic School Grogol Sukoharjo Tahun 2012. Jurnal Kebidanan Indonesia: Journal of Indonesia Midwifery 4.2. https:// doi.org/10.36419/jkebin.v4i2.77

Hidayati, F., Kaloeti, D. V.S., \&Karyono. (2011). Peran Ayah Dalam Pengasuhan Anak. Insight: Jurnal Ilmiah Psikologi, 17(2), 81. https:/ / doi.org/10.26486/psikologi.v17i2.687

Indira, P. M. (2017). Kapasitas Pengasuhan Orangtua dan Faktor-Faktor Pemungkinnya Pada Keluarga Miskin Perkotaan. Indigenous: Jurnal Ilmiah Psikologi, 2(1). https:// doi.org/10.23917/indigenous.v2i1.4433

Ishii-Kuntz, M. (2013). Work Environment and Japanese Fathers' Involvement in Child Care. Journal of Family Issues, 34(2), 250-269. https:/ / doi.org/10.1177/0192513X12462363

Isnaningsih, A., \& Rohman, A. (2019). Participation of Mothers Who Work in Religious Activities Towards Child Behavior. Jurnal Obsesi : Jurnal Pendidikan Anak Usia Dini, 3(1), 199. https:// doi.org/10.31004/obsesi.v3i1.157

Lestari, S. (2012). Psikologi Keluarga. Kencana Prenada Media Group.

Lidyasari, A. T. (2013). Pola Asuh Otoritatif Sebagai Sarana Pembentukan Karakter Anak Dalam Setting Keluarga. Http://Staff.Uny.Ac.Id/, 1-10.

Matondang, E. S. (2016). Perilaku Prososial (Prosocial Behavior) Anak Usia Dini Dan Pengelolaan Kelas Melalui Pengelompokan Usia Rangkap (Multiage Grouping). Edu Humaniora: Jurnal Pendidikan Dasar Kampus Cibiru, 8(1), 34. https://doi.org/10.17509/eh.v8i1.5120

Murti, H. A. S. (2013). Efikasi Diri Ayah Dalam Pengasuhan Anak Usia Dini. Temu Ilmiah Nasional Psikologi Pendidikan Anak Usia Dini Tahun 2012, 155-168.

Muslima. (2015). Pola Asuh Orang Tua Terhadap Kecerdasan Finansial Anak. Gender Equality: International Journal of Child and Gender Studies, 1(1), 111-124.

Nauli, V. A., Karnadi, K., \& Meilani, S. M. (2019). Peran Ibu Pedagang Pasar 24 Jam Terhadap Perkembangan Moral Anak (Penelitian Studi Kasus di Kota Bekasi). Jurnal Obsesi: Jurnal Pendidikan Anak Usia Dini, 3(1), 241. https:/ / doi.org/10.31004/obsesi.v3i1.179

Newton, E. K., Laible, D., Carlo, G., Steele, J. S., \& Mc Ginley, M. (2014). Do Sensitive Parents Foster Kind Children, Or Vice Versa? Bidirectional Influences Between Children's Prosocial Behavior And Parental Sensitivity. Developmental Psychology, 50(6), 18081816. https:// doi.org/10.1037/a0036495

Novianty, A., \& Gunadarma, U. (2016). The Influence of Authoritarian Parenting To Emotional Intelligence in. 9(1), 17-25.

Pasaribu, R. M., Hastuti, D., \& Alfiasari. (2013). Gaya Pengasuhan Permisif Dan Rendahnya Sosialisasi Nilai Dalam Keluarga Beresiko Terhadap Penurunan Karakter Remaja. 6(3), 163171. https:// doi.org/10.24156/jikk.2013.6.3.163

Permendikbud. (2014). Peraturan Menteri Pendidikan dan Kebudayaan Republik Indonesia Nomor 137 Tahun 2014 Tentang Standar Nasional Pendidikan Anak Usia Dini (Vol. 8, Issue 33).

Purnamasari, S. E. (2015). The Role Of Fathers In Children' S Upbringing. 17(2), 81-90. 
Ranson, G. (2015). Fathering, Masculinity and the Embodiment of Care. Palgrave Macmillan.

Sanders, M. R., \&Mazzucchelli, T. G. (2018). The power of positive parenting: Transforming the lives of children, parents, and communities using the Triple P system.Oxford University Press.

Santrock, J. W. (2012). Perkembangan Masa Hidup: Edisi Ketiga Belas, Jilid 1. Terjemahan: Widyasinta, $B$.

Scrimgeour, M. B., Blandon, A. Y., Stifter, C. A., \& Buss, K. A. (2013). Cooperative Coparenting Moderates The Association Between Parenting Practices And Children's Prosocial Behavior. Journal of Family Psychology. https:// doi.org/10.1037/a0032893

Seward, R. R., \& Rush, M. M. A. (2015). Fathers , Fatherhood and Fathering Across Cultures: Convergence or Divergence. UCD School Of Applied Social Science. https://www.researchgate.net/publication/304140871

Sigelman, C. K., \& Rider, E. A. (2012). Life-Span Human Development.Cengage Learning.

Sofiani, I. K., Mufika, T., \& Mufaro'ah, M. (2020). Bias Gender dalam Pola Asuh Orangtua pada Anak Usia Dini. Jurnal Obsesi: Jurnal Pendidikan Anak Usia Dini, 4(2), 766. https:// doi.org/10.31004/obsesi.v4i2.300

Sugiyono. (2013). Metode Penelitian Pendidikan Pendekatan Kuantitatif,. Kualitatif, dan RED. Alfabeta.

Sumargi, A. M., \& Kristi, A. N. (2017). Well-Being Orang Tua, Pengasuhan Otoritatif, dan Perilaku Bermasalah pada Remaja. Jurnal Psikologi. https:/ / doi.org/10.22146/jpsi.25381

Suryana. (2014). Hakikat anak usia dini dasar-dasar pendidikan TK.Universitas Terbuka.

Tekin. (2012). Father Involvement in Early Childhood Education. International Conference on Educational Research, Bangkok, Thailand, 1, 453-456. https://doi.org/10.1007/978-0-38771799-9_174

Wiyani, N. A. (2016). Konsep Dasar Paud. Gava Media.

Yeung, W. J. J. (2013). Asian Fatherhood. Journal of Family Issues, 34(2), 141-158. https:/ / doi.org/10.1177/0192513X12461133 